\title{
Synthesis of biologically active molecules by imprinting polymerisation
}

\author{
S. A. Piletsky ${ }^{1,2}$, E. V. Piletska ${ }^{1}$, T. A. Sergeyeva ${ }^{2}$, I. A. Nicholls ${ }^{3}$, \\ D. Weston ${ }^{1}$ A. P. F. Turner ${ }^{1}$ \\ ${ }^{1}$ Institute of BioScience and Technology, Cranfield University at \\ Silsoe, Bedfordshire, MK45 4DT, UK \\ 2 Institute of Molecular Biology and Genetics of National Academy of Sciences of Ukraine \\ 150 Zabolotnogo str., 03143, Kiev, Ukraine \\ 3 \\ Box 905, S-39129 Kalmar, Sweden \\ E-mail: t_sergeyeva@yahoo.co.uk
}

\begin{abstract}
Highly cross-linked molecularly imprinted polymers (MIPs) are synthetic materials with properties mimicking those of natural receptors. Here we describe an ability of MIP nanoparticles to manifest biological activity. Molecularly imprinted polymers were synthesised by co-polymerisation of urocanic acid. $N, N^{\prime}$-bisacryloyl piperazine in the presence of herbicide binding DI protein, ground and separated from the template by washing and ultrafiltration. It was demonstrated that MIP nanoparticles retained affinity to the template. Moreover, imprinted polymers were able to activate chloroplast photosystem $I I$ in in vitro experiments. This provides the first example of the use of imprinted polymers for the attenuation of a biological system and opens new possibilities for their application in pharmacology, biotechnology and medicine.
\end{abstract}

Key words: molecularly imprinted polymers, DI protein, Hill reaction.

Introduction. Since being first described in 1972, molecularly imprinted polymers (MIPs) have attracted broad interest from scientists engaged in the development of chromatographic adsorbents, sensors, catalysts, enzymes and receptor mimics $[1-4]$. The particular features which make them the target of intense investigation are striking resemblance of the MIP binding properties to those of natural receptors [4-6] and their inherent stability, low cost and ease of preparation [7, 8]. However, MIPs suffer in comparison with natural antibodies and receptors in clinical and pharmaceutical applications due to their relatively large particle size and the lack of true water compatibility.

(C) S. A. PILETSKY, E. V. PILETSKA, T. A. SERGEYEVA, 1. A. NICHOLLS, D. WESTON, A. P. F. TURNER, 2006
We report here the preparation of water-soluble cross-linked nano-sized MIP particles through the extensive polymer grinding and ultrafiltration. The imprinted polymer was prepared in the presence of thylakoid membrane D1 protein. DI protein represents a good model system because it is stable in vitro, its role in photosynthetic process, where it mediates the electron flow passing through the Photosystem II, is well known and its activity can be easy monitored using Hill reaction $[9,10]$. In D1 structure one can envisage two possible interaction sites for MIP: internal (herbicide binding site) and external, exposed to cytoplasm.

Our intention was to investigate the ability of D1-specific MIP upon binding to the D1 to alter the photosynthetic process either through the displa- 
cement of the electron acceptor $Q_{B}$ from herbicide binding site, or through the interaction with D1 external site. Evidence for such a biological activity of synthetic polymers can open a new way for the application of MIP nanoparticles in pharmacology, analytical chemistry and biotechnology as well as in the fundamental research of molecular recognition phenomena. Furthermore, the analysis of the influence of extensive grinding on the recognition characteristics of polymer was of intend in order to establish the minimal particle size necessary for maintaining molecular «memory» and specificity.

Materials and Methods. All chemicals were obtained from commercial sources and used as received.

MIP synthesis. D1 protein was obtained from pea leaves as previously described [10]. Purified (95\%) lyophilised D1 protein (10 mg) was extracted with hexane, mixed with $\mathrm{N}, \mathrm{N}^{\prime}$-bisacryloyl piperazine (BAP) (194 mg), urocanic acid (UA) $(6.9 \mathrm{mg}$ ), ammonia persulphate $\left(\mathrm{NH}_{4}\right)_{2} \mathrm{~S}_{2} \mathrm{O}_{8}(10 \mathrm{mg})$ and $\mathrm{H}_{2} \mathrm{O}$ $(200 \mu 1)$. Polymerisation was initiated by adding $2 \mu 1$ of $30 \% \mathrm{~N}, \mathrm{~N}, \mathbf{N}^{\prime}, \mathrm{N}^{\prime}$-tetramethylethylenediamine (TEMED) solution followed by heating at $80^{\circ} \mathrm{C}(12$ h). The control polymers were prepared in the absence of D1 protein (Blank) and in the presence of irrelevant, bovine serum albumin (BSA). Polymers were washed with $0.1 \mathrm{M} \mathrm{HCl}$, ground, filtered through the glass filter (N3) and centrifuged through Ultra-Spin Macrofilters («Roth», Germany) separating molecules with molecular weight $<5 \mathrm{kDa}, 5-$ $10 \mathrm{kDa}$ and $>10 \mathrm{kDa}$ (yield is $\sim 0.2 \mathrm{mg} /$ fraction). Additionally these fractions were analysed by gel filtration chromatography (GFC) in $100 \mathrm{mM}$ sodium phosphate buffer, pH 7.5, using Superdex Peptide HR $10 / 30$ column, calibrated with peptides and proteins. The absorbance of all solutions was measured at $260 \mathrm{~nm}$.

Chromatography of the polymers on affinity column with immobilised DI protein (DI-column). To prepare D1-Sepharose, D1 protein $(0.1 \mathrm{~g})$ was added to activated CH-Sepharose 4B (5 g) («Pharmacia Fine Chemicals», Sweden) in phosphate buffer (10 mM, $\mathrm{pH} 7.5$ ) and left overnight at $40^{\circ} \mathrm{C}$. The immobilization rate was $6 \mathrm{mg} / \mathrm{g}$ of sorbent. Chromatography column was packed with $3 \mathrm{~g}$ of D1-Sepharose. The column was equilibrated with eluent ( $25 \mathrm{mM}$ sodiumphosphate buffer, $\mathrm{pH} 7.5$, flow rate $0.22 \mathrm{ml} / \mathrm{min}$ ) at room temperature. An aliquot $(100 \mu 1)$ of the polymer solution (fraction $5-10 \mathrm{kDa}$ ) was injected into the column and the retention times of the peaks were measured. All eluted peaks were analyzed additionally by GFC.

Influence of the polymers on the activity of thylakoid membranes. The thylakoid activity was measured as previously described [10]. An aliquot (30 $\mu \mathrm{l})$ of thylakoid solution (1 $\mu \mathrm{g}$ chlorophyll in probe) containing sucrose $(0.35 \mathrm{M})$ and BSA (1\%) was mixed with polymer solution $(20 \mu 1)$, and DPIP $(100 \mu \mathrm{l}, 0.3 \mathrm{mM})$ in Tris- $\mathrm{HCl}$ buffer $(0.1 \mathrm{M}, \mathrm{pH} 7.5)$ in the microplate wells. The samples were illuminated for 10 min with a $100 \mathrm{~W}$ lamp and the absorbance was measured at $530 \mathrm{~nm}$ using a Dynatech reader (Germany). The activity of thylakoid membranes was calculated from the amount of reduced DPIP, concentration of chlorophyll and the time of illumination.

Results and Discussion. We have polymerised the functional monomer urocanic acid, containing carboxylic and imidazole residues, essential for the protein recognition and water-soluble cross-linker $\mathrm{N}, \mathrm{N}^{\prime}$-bisacryloyl piperazine [11] in the presence of D1 protein. Judging from our experience, UA is a monomer superior to methacrylic acid, traditionally used in molecular imprinting, being able to form a stronger complex with a template. It can also be co-polymerised with BAP giving polymer with $99 \%$ yield. The synthesised polymer was ground, washed from the template and centrifuged through microfilters to yield three fractions: $<5 \mathrm{kDa}, 5-10 \mathrm{kDa}$ and $>10 \mathrm{kDa}$. These fractions were analysed by GFC giving peaks with average molecular weight $0.8 \mathrm{kDa}$ and $0.2 \mathrm{kDa}$ (fraction $<5 \mathrm{kDa}$ ), $6.7 \mathrm{kDa}$ (fraction $5-10 \mathrm{kDa}$ ) and $18 \mathrm{kDa}$ (fraction $>10 \mathrm{kDa}$ ). Taking into account the fact that the molecular weight of D1 protein is $32 \mathrm{kDa}$, we did not expect the template to be present in the polymer fractions. Minor quantities of the protein residues (presumably short peptides) however were found in the fraction with molecular weight $<5 \mathrm{kDa}$, as was determined using BCA-assay [12].

The affinities of the imprinted and blank polymer (prepared in the absence of a template) for templates were analysed by liquid chromatography using a Sepharose column derivatised with D1 protein (D1column). The elution profiles of the MIP and blank polymers on the D1-column are presented in Fig. 1.

The peaks eluted first correspond to residues of non-polymerised monomers. The capacity factors, which reflect polymer affinity, were much higher for the MIP than for the blank polymer $\left(K_{\text {MIP }}=1.11 \pm\right.$ \pm 0.06 and $\mathrm{K}_{\mathrm{Blank}}=0.56 \pm 0.05$; separation factor $\alpha=$ 


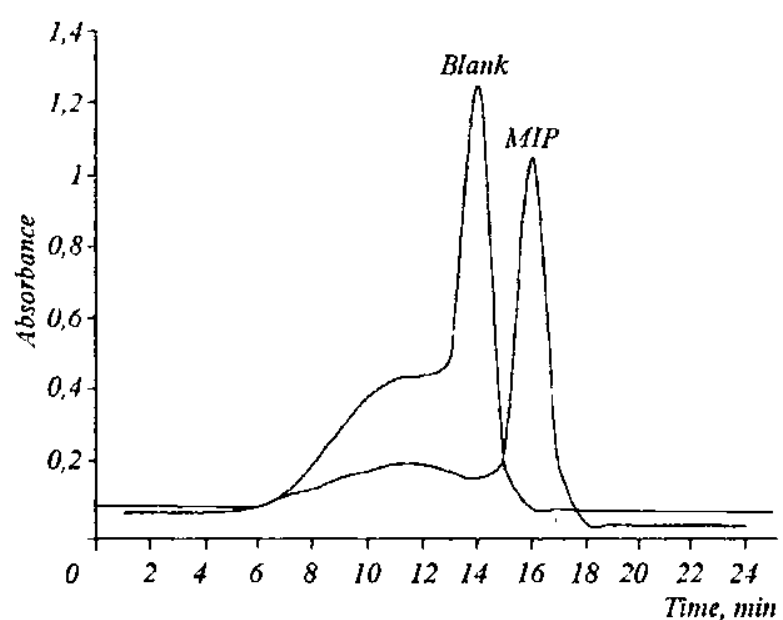

Fig. 1. Chromatography of the polymers on a column with immobilized Dl protein in $25 \mathrm{mM}$ sodium phosphate buffer, $\mathrm{pH} 7.5$. Flow rate $0.22 \mathrm{ml} / \mathrm{min}$. Injections $-100 \mu \mathrm{l}$ of the polymer solution (fraction $5-10 \mathrm{kDa}$ ) at a concentration of $1 \mathrm{mg} / \mathrm{ml}$. Detection was performed at $260 \mathrm{~nm}$. Capacity factors for blank and imprinted polymers were calculated using equation: $K_{i}-\left(T_{i}-T_{0}\right) / T_{0}$, where $K_{i}=$ capacity factor of an analyte, $T_{i}=$ retention time of analyte, and $T_{0}$ - retention time of non-interacting species. In our experiments free volume and $T_{0}$ were calculated using injection of diluted buffer solution

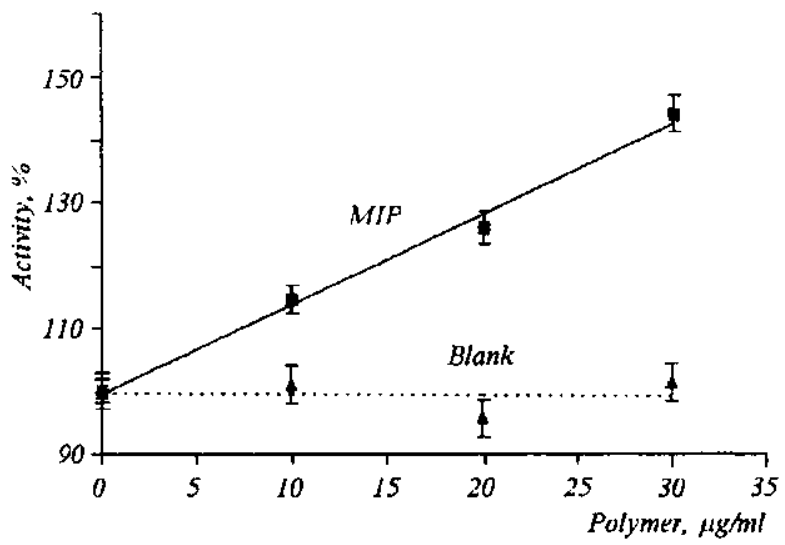

Fig. 2. Influence of the polymers on thylakoid activity in vitro. Reaction mixture $(150 \mu \mathrm{l})$ contained: thylakoid suspension (1 $\mu \mathrm{g}$ chlorophyli) and DPIP $(9 \mu \mathrm{g})$ in Tris- $\mathrm{HCl}$ buffer $(0.1 \mathrm{M}, \mathrm{pH} 7.5)$. All measurements were done in triplicate

$=1.98$ ). For a non-derivatised column the capacity factor for MIP (fraction 5-10 kDa) was the same as for a blank polymer $\left(K_{\mathrm{MIP}}=0.60 \pm 0.06\right)$. This provided a clear indication of the role of the imprinting process and proved that the affinity of the MIP to D1-column results from the interaction of the polymer with the immobilised template. From these results we can assume that at least a part of the polymer specific structure is preserved upon grinding.

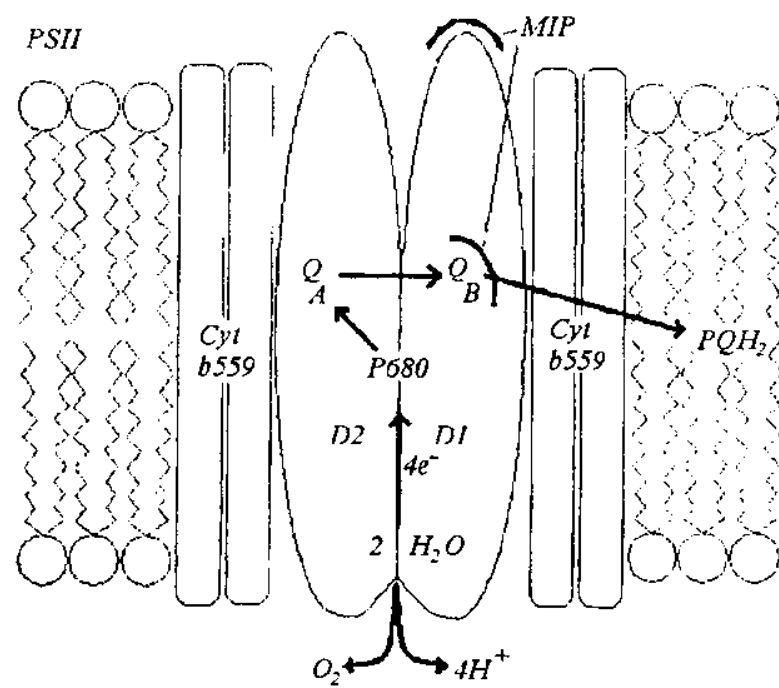

Fig. 3. Schematic structure of the Photosystem II core with Dl protein. $Q_{A}$ and $Q_{B}$ - bound plastoquinines; $P Q H_{2}-$ reduced plastoquinone, Cytb559-b-type cytochrome; $D I$ and $D 2-$ core proteins of the PS II, involved in the electron transport; MIPpolymer formed in the presence of $\mathrm{D} 1$ protein with possible sites for its interaction

The biological activity of the polymers was analysed in vitro using the Hill reaction [9]. Upon illumination thylakoids reduced the dichlorphenolindophenol (DPIP)-electron acceptor, changing its absorbance spectra. The activity of thylakoids can be calculated from the amount of DPIP reduced. We had anticipated that the imprinted polymer upon binding to D1 protein would influence this reaction. In our experiments the clear increase (up to $45 \%$ for $30 \mu \mathrm{g} / \mathrm{ml}$ of polymer concentration) in activity of thylakoid membranes was observed (Fig. 2) which suggests that the target of MIP action is not the herbicide-binding site but rather the external site of the D1 protein (Fig. 3).

The ability of polymers to enhance the stability and activity of thylakoids and enzymes has previously been demonstrated [13-15], though this effect has been ascribed to the inhibition of proteolysis or non-specific stabilisation of the protein structure by restricting unfolding [16]. In our experiments, however, we were able to select the molecular target in the photosystem complex for the interaction with MIPs and enhance the biological effect using imprinting with D1 protein. A good indication of the selectivity of the interaction is the negligible influence of the blank polymer and monomers (UA and BAP) on the Hill reaction (Fig. 3 and 4). Additionally the blank polymer and D1 protein were not able to 


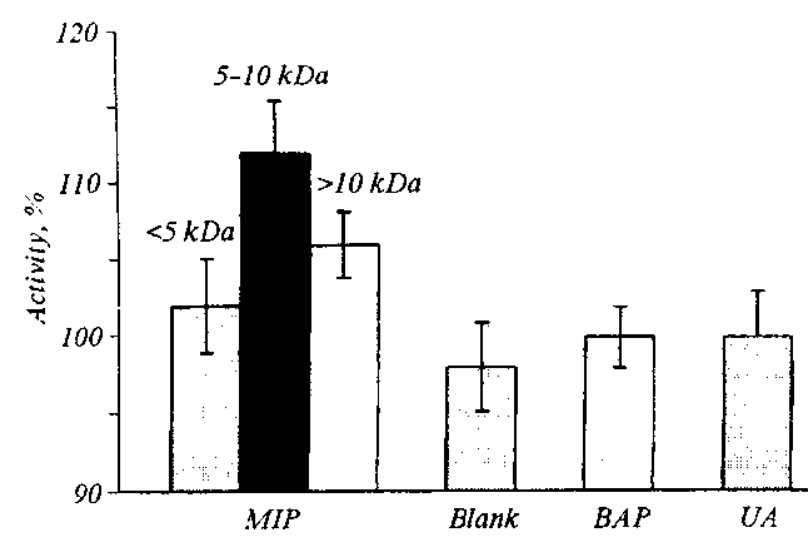

Fig. 4. Influence of the size of the polymer fractions and monomers (concentration $10 \mu \mathrm{g} / \mathrm{ml}$ each) on thylakoid activity. Blank fraction of the blank polymer with size $5-10 \mathrm{kDa}$ (for reaction conditions see legend to Fig. 3). All measurements were done in triplicate

change the activity of thylakoids. We also found that polymer prepared in the presence of BSA had no biological activity. We thus conclude that the activation of the thylakoids by D1-specific MIP is induced by the selective interaction with D1 protein so as to provide partial stabilisation of the photosystem complex structure, and preventing its interaction with proteases or free radicals. The influence of MIP particle size on thylakoid activity was also investigated (Fig. 4).

The lower activation achieved for the polymer fraction with a particle size smaller than $5 \mathrm{kDa}$ can be explained by the partial destruction of the binding sites. The reason for slightly lower activity of $>10 \mathrm{kDa}$ fraction in comparison with $5-10 \mathrm{kDa}$ fraction could be relative difficulty in permeation of this fraction through the thylakoid membranes. It can be concluded that in order to possess affinity for D1 protein MIPs should contain at least 25-30 monomer units with pre-determined primary monomer sequence.

Conclusions. To our knowledge, this is the first report of a MIP capable of mediating biological activity. These water-soluble MIPs have an affinity to the original template and superior activity to randomly synthesised polymers. They can be prepared easier than specifically designed discrete organic structures. Although the yield of the polymer is low, MIP nanoparticles can be used in the area of fundamental research of molecular recognition phenomena. It is anticipated that imprinted polymers can be practically useful in analytical chemistry, biotechnology, in the pharmaceutical and food industries.

Acknowledgement. We are grateful to Dr. H.S. Andersson for helpful discussion of this work. S.P. also acknowledges with gratitude the fellowship from Leverhulme Trust.

С. А. Пілецький, О. В. Пілецька, Т. А. Сергеєва, I. А. Ніколс, Д. Вестон, А. П. Ф. Тернер

Синтез біологічно активних молекул методом молекулярного імпринтингу

Резюме

Молекулярно-імпринтовані полімери (МIЛ) є сітчастими полімерами з високим ступенем зшивання, які імітують біологічні рецептори. В даній роботі вперие продемонстровано біологічну активність матричних полімерних наночастинок. МІП отримано внаслідок співполімеризації уроканової кислоти та $N, N^{\prime}$-бісакрилоїлпіперазину за присутності гербіцид-зе язувального білка ДI як матричної молекули. Далі його подрібнювали $i$ за допомогою ультрафільтрацї̈ виділяли фракцію матричних полімерних наночастинок. Показано, що такі частинки мали афінність до матричних молекул, а також здатність активувати фотосистему II хлоропластів в ехспериментах in vitro. Подібні властивості матричних полімерних наночастинок відкривають широкі перспективі їхнього використання в фармаколохії, біотехнолосії та медицині.

С. А. Пилецкий, Е. В. Пилецкая, Т. А. Сереевва, И. А. Николс, Д. Вестон, А. П. Ф. Тернер

Синтез биологически активных молекул методом молекулярного импринтинга

Резғоме

Молекулярно-импринтированные полимеры (МИП) представляют собой сетчатые полимеры с высокой степенью сиивания, имитирующие биологиеские рецепторы. $B$ данной работе впервые продемонстрирована биолосическая активность матричних полимерных наночастии. МИП получены вследствие сополимеризации урокановой кислоты и $N, N^{\prime}$-бисакрилоил пиперазина в присутствии гербицид-связывающего белка дһl как матричной молекуль. Далее их измельчали и с помощью ультрафильтрации выделяли фракцио матричных полимерных наночастиц. Показано, что такие частицы обладали аффинностью к матричным молекулам, а также способно стью активировать фотосистему II хлоропластов в экспериментах in vitro. Подобные свойства матричних полимерных наночастии открывают иирокие перспективы их использования в фармакологии, биотехнолосии и медицине.

\section{REFERENCES}

1. Wulff G., Sarhan A. The use of polymers with enzymesanalogous structures for the resolution of the racemates // Angew. Chem. Int. Ed. Engl.-1972,-11.-P. 341-344.

2. Piletsky S. A., Piletskaya E. V., Panasyuk T. L., Elskaya A. $V$., Levi R., Karube I., Wulff $G$. Imprinted membranes for sensor technology: Opposite behavior of covalently and noncovalently imprinted membranes // Macromolecules. - 1998.31.-P. 2137-2140

3. Wulff $G$., Gross T., Schonfeld $R$. Enzyme models based on 
molecularly imprinted polymers with strong esterase activity // Angew. Chem. Int. Ed. Engl.-1997.-36.-P. 1962-1964.

4. Vlatakis G., Andersson L. I., Muller R., Mosbach K. Drug assay using antibody mimics made by molecular imprinting // Nature.-1993.-361.-P. 645-647.

5. Andersson L. I, Muller R., Vlatakis G., Mosbach $K$. Mimics of the binding sites of opioid receptors obtained by molecular imprinting of enkephalin and morphine // Proc. Nat. Acad. Sci. USA.-1995.-92.-P. 4788-4792.

6. Berglund J., Nicholls I. A., Lindbladh C., Mosbach $K$ Recognition in molecularly imprinted polymer $\alpha 2$-adrenoceptor mimics // Biomed. Chem. Lett.-1996.-6.-P. 2237-2242.

7. Kriz D., Mosbach $K$. Competitive amperometric morphine sensor based on an agarose immobilized molecularly imprinted polymer // Anal. Chim. Acta.-1994.-300.-P. 71 $\rightarrow 75$.

8. Andersson H. S., Nicholls I. A. Molecular imprinting: recen innovations in synthetic polymer receptor and enzyme mimics // Recent Res. Develop. Pure \& Appl Chem.-1997.-1.P. 133-157.

9. Hill R., Whittinghan C. P., Photosynthesis.-New York: John Wiley, 1955.-164 p.

10. Piletskaya E., Piletsky S., Lavrik N., Masuchi Y., Karube I. Towards the D1 protein application for the development of sensors specific for herbicides // Anal. Lett. -1998.-31.P. 2577-2589.

11. Piletsky S. A., Andersson H. S., Nicholls I. A. Combined hydrophobic and electrostatic interaction based recognition in moleculariy imprinted polymers // Macromolecules. - 1998... 32.-P. 633-636

12. Smith P. K., Krohn R. I., Hermanson G. T., Mallia A. K., Gartner F. H., Provenzano M. D., Fujimoto E. K., Goeke N. M., Olson B. J., Klenk D. C. Measurement of protein using bicinchoninic acid // Anal. Biochem. -1985.-150.-P. 7685.

13. Rouillon R., Mestres J.-J., Marty J.-L. Entrapment of chloroplasts and thylakoid in polyvinylalcohol-SbQ. Optimization of membrane preparation and storage conditions // Anal. Chim. Acta.-1995.-311.-P. 437-442.

14. Gonzalez-Navarro $H$., Braco $L$. Lipase-enhanced activity in flavour ester reactions by trapping enzyme conformers in the presence of interfaces // Biotechnol, and Bioengin.-1998.59. -P. 122-127.

15. Cong L., Kaul R., Dissing U., Mattiasson B. A. A model study on eudragit and polyethyleneimine as soluble carriers of alpha-amylase for repeated hydrolysis of starch // J. Biotechnol. $-1995 .-42 .-P$. 75-84.

16. Garcia D., Ortega F., Morty J. L. Kinetics of thermal inactivation of horseradish peroxidase: stabilizing effect of methoxypoly(ethylene glycol) // Biotechnol. and Appl. Biochem1998.-27.-P. 49-54.

УДК $544.725+544.722 .21+577.21$ Надійшла до редакції 18.03.05 